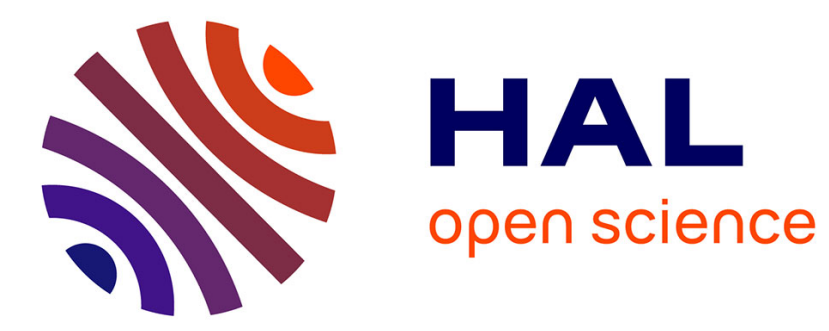

\title{
Environmental influence on canopy phenology in the dry tropics
}

Frederic C Do, Venceslas A Goudiaby, Olivier Gimenez, Amadou L Diagne, Mayecor Diouf, Alain Rocheteau, Leonard E Akpo

\section{- To cite this version:}

Frederic C Do, Venceslas A Goudiaby, Olivier Gimenez, Amadou L Diagne, Mayecor Diouf, et al.. Environmental influence on canopy phenology in the dry tropics. Forest Ecology and Management, 2005, 215, pp.319 - 328. 10.1016/j.foreco.2005.05.022 . hal-03498945

\section{HAL Id: hal-03498945 \\ https://hal.science/hal-03498945}

Submitted on 25 Dec 2021

HAL is a multi-disciplinary open access archive for the deposit and dissemination of scientific research documents, whether they are published or not. The documents may come from teaching and research institutions in France or abroad, or from public or private research centers.
L'archive ouverte pluridisciplinaire HAL, est destinée au dépôt et à la diffusion de documents scientifiques de niveau recherche, publiés ou non, émanant des établissements d'enseignement et de recherche français ou étrangers, des laboratoires publics ou privés. 
ENVIRONMENTAL INFLUENCE ON CANOPY PHENOLOGY IN THE

\section{DRY TROPICS}

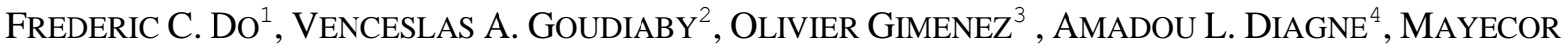

${ }^{1}$ IRD-UR060, Centre d'Ecologie Fonctionnelle et Evolutive, 1919 Rte de Mende, 34293 Montpellier France

$6 \quad{ }^{2}$ Faculté des Sciences et techniques (Biologie Végétale), Université Cheikh Anta Diop, BP 5005 Dakar, Sénégal

${ }^{3}$ CNRS, Centre d'Ecologie Fonctionnelle et Evolutive, 1919 Rte de Mende, 34293 Montpellier France

$8{ }^{4}$ Institut des Sciences de l'Environnement, Université Cheikh Anta Diop, BP 5005 Dakar, Sénégal 
12 In the dry tropics, leaf activity of dominant woody species in the dry season is fundamental for ecosystem vitality. Prediction of the potential impact of climate change on leaf phenology of these species is a major challenge in Tropical Ecology. However, the environmental controls of inter-annual variation of leaf flushing and leaf fall are poorly understood. We focused on a comparison between the two major drivers considered in the dry tropics: soil water availability and atmospheric conditions. We performed a 5 year phenological study of 39 individual trees of Acacia tortilis ssp. raddiana in the northern Sahelian zone. Our data show that a significant inter-annual variation, up to 2.0 months, affects both the timing of the peaks of leaf flush and leaf fall. The full canopy stage lasted between 5 and 8 months, broadly including the rainy season and the "cool" dry season, the timing of leaf flush peak varying from one month before the first rains to one month after. The trees have access to a deep water table $(31 \mathrm{~m})$ which had no significant inter-annual variation. Predictions of canopy fullness from upper soil water availability (SWA), temperature, relative humidity and vapor pressure deficit (VPD),

24 were compared applying polynomial logistic regressions pooling all the years. We found that atmospheric conditions and particularly VPDmax (midday value) were far better predictors than SWA. Simulations based on VPDmax, significantly predicted the inter-annual variations both in the timing of leaf flush peak $(\mathrm{RMSE}=0.5$ month) and in the timing of leaf fall peak (RMSE $=0.6$ month). We conclude that the inter-annual variation of canopy phenology is mainly a fine tuning to atmospheric conditions.

Key words: Sahelian Africa; Acacia tortilis; canopy fullness; leafflushing; leaf fall; vapour pressure deficit; soil water availability. 


\section{INTRODUCTION}

36 In dry tropical regions such as Sahelian Africa, leaf activity of dominant woody species in the dry season is a keystone resource for domestic herbivores, wildlife and ecosystems as a whole (Le Houérou 1989). Prediction of the potential impact of climate change on the timing of leaf flushing and leaf fall, i.e. leaf phenology, is a new and major challenge in Tropical Ecology.

Authors are in agreement on a primary genetic control and an influence of day length on leaf phenology (Halevy and Orshan 1973; Reich and Borchert 1984; Borchert 1994 a\&b; Reich 1995; Williams et al. 1997, Morellato et al. 2000). The controversy is over precisely which environmental control can best explain inter-annual and inter-site variations in the timings of leaf flush and leaf fall. The hypothesis that has gained most support is that of control by soil water availability through tree water status (Borchert 1994 a,b,c; Eamus and Prior 2001). However, several irrigation experiments in the field have shown little impact of soil water availability on leaf phenology and a number of authors have suggested that evaporative demand may also be an important driver (Wright and Cornejo 1990; Duff et al. 1997; Myers et al. 1998).

In conducting a five and a half years study on 39 individuals of Acacia tortilis in the Sahelian zone, we have chosen to investigate the issue by using an inter-annual analysis, which is rare in the bibliography (Poupon 1979, Corlett and Lafrankie 1998). The Sahelian zone sensu stricto represents one of the driest savannas with $200-400 \mathrm{~mm} \mathrm{y}^{-1}$ of rainfall and with high inter-annual variability (C.V. $=37 \%$ ), potential evaporation is in excess of $2000 \mathrm{~mm} \mathrm{y}^{-1}$ and groundwater is usually located deeper than $30 \mathrm{~m}$

54 (Le Houerou 1989). Acacia tortilis (Forsk.) Hayne ssp. raddiana (Savi) Brenan, is a dominant tree of the area which is classified as semi-evergreen or semi-deciduous (Breman and Kessler 1995, Le Floc'h and Grouzis 2003), i.e. the loss of leaves which takes place in the late dry season is and its rate varies with years, sites and individuals. The tree regularly exhibits leaf flush before the onset of rains. It is known that its roots can reach the deep water table (Lhote 1961; Deans et al. 2004) in common with numerous woody species of low-rainfall areas. However, high seasonal fluctuations of predawn

60 leaf water potential attest to the influence of soil water availability near the soil surface on tree water status (Berger et al. 1996). In this study, we focused on the annual attainment and maintenance of the 
62 full canopy stage in the tree population. The full canopy stage of a tree is assessed when the proportion of the branches supporting green expanded leaves represents more than $50 \%$ of those in the canopy.

64 Such simple phenological assessment at a monthly interval is a good indicator of the seasonal transpiration and activity of the tree (Do and Rocheteau 2003). The timings when foliation rose above or fell beneath the $50 \%$ value defined the timings of leaf flushing and leaf fall peaks, respectively. These timings allow the calculation of full canopy stage duration. Using concurrent measurements of climatic conditions and soil water availability, the study had two objectives. The first objective was to assess the inter-annual variation in the timings of leaf flushing and leaf fall and by consequence the changes in the full canopy stage duration and period in the year. The second objective was to determine which environmental variable can best explain inter-annual change in the timings of leaf flushing and leaf fall peaks. In this water-controlled biome, we focused on a comparison between soil water availability and the following atmospheric variables: temperature, relative humidity and vapour pressure deficit which is a combination of the former variables and the driving force of water loss.

\section{METHODS}

\section{Location, climate and vegetation}

The study was carried out in northern Senegal, near Souilene Village $\left(16^{\circ} 20^{\prime} \mathrm{N}, 15^{\circ} 25^{\prime} \mathrm{W}\right)$ located 20

$\mathrm{km}$ south of Dagana in the grazing land ecosystem of the sandy Ferlo. Annual rainfall averages 280 $\mathrm{mm}$, mean annual temperature is $28.7^{\circ} \mathrm{C}$ and average maximum and minimum temperatures are, respectively: 41 and $22{ }^{\circ} \mathrm{C}$ for the hottest month (May) and 31 and $14{ }^{\circ} \mathrm{C}$ for the coldest month (January). The sparse woody community is dominated by three species: Acacia tortilis and Balanites aegyptiaca (L.) Del, for the tree layer (90 individuals $\mathrm{ha}^{-1}$ ) and Boscia senegalensis (Pers.) Lam for the shrub layer (50 individuals ha $\left.{ }^{-1}\right)$. The soil is very deep and sandy (90\% sand).

\section{Population and measurements}

The studied population included 39 mature individuals located in a 1 ha area that has been protected since 1989. Trunk diameter, which was measured $30 \mathrm{~cm}$ above the soil, varied from 5 to $45 \mathrm{~cm}$, with $70 \%$ of the population having diameters between 15 and $30 \mathrm{~cm}$. Tree height ranged from 5 to $10 \mathrm{~m}$. 
Leics, UK), which recorded hourly values of air temperature, relative humidity, incoming short wave

radiation and rainfall. The water Vapour Pressure Deficit (VPD) was calculated from air temperature (T) and relative humidity $(\mathrm{RH})$ :

$$
\mathrm{VPD}=\mathrm{e}_{\mathrm{s}}(\mathrm{T})-\mathrm{e} \quad \text { and, } \quad \mathrm{e}=\mathrm{RH} * \mathrm{e}_{\mathrm{s}}(\mathrm{T})
$$

where $e_{s}(T)$ is the saturation vapour pressure at air temperature $T$ and e, the actual vapour pressure.

94 Soil moisture was measured to a depth of 4 meters by neutron probe (Solo 25, Nardeux S.A., Les Ulis, France) using six access tubes. The soil wetting front rarely exceeded one meter depth. Soil water

availability (SWA) is expressed for the layer 0-100 $\mathrm{cm}$ deep, calculated between moisture contents at field capacity and the driest moisture contents which were less than those prevailing at a water potential of $-1.5 \mathrm{MPa}$. The soil profile down to the water table was augered by the Geological Department of Dakar University (Dr Abdoulaye Faye). Samples were taken every $0.5 \mathrm{~m}$. Actual moisture content and moisture equivalent to $-1.5 \mathrm{MPa}$ were determined in the laboratory. Over the period June 1995- August 2000, phenological observations and soil measurements were carried out every month in the dry season and twice a month in the rainy season, except in August 1995 and 1997. Climatic data were not available between 13 and 18 April 1996 and between 29 September and 10

October 1996.

\section{Assessment of phenological stages}

106 For each tree, a phenological stage for the foliage was allocated according to the 6 following categories taking into account the proportion of branches bearing green expanded leaves in the canopy

108 (Grouzis and Sicot 1980): 0, leafless, 0\%; 1, leaf buds opening, $<10 \%$; 2, start of leaf expansion, 10 $50 \%$ of the branches; 3 , full canopy, $>50 \%$; , start of leaf senescence, changing colour, $<50 \%$; 5 ,

110 full leaf senescence or fall, $<10 \%$.

\section{Data analysis}

112 To express canopy fullness, the phenological stages were converted to their midrange percentage value of branches bearing green expanded leaves in the canopy: $0,0 \% ; 1,5 \% ; 2,30 \% ; 3$, $11475 \% ; 4,30 \% ; 5,5 \%$. Thus the maximum value of canopy fullness is 75 by definition.

The timings of leaf flush or leaf fall peaks were calculated for each tree by linear interpolation such as 116 the time when the canopy fullness rose above or fell below the $50 \%$ value in the long term $(>1$ 
month). Time is expressed in numerical values of months (mo.), e.g. 6.5 for the middle of June.

118 Because phenological cycles are displayed across two years, we use for simplicity's sake, the year of the rainy season to name the phenological cycle, e.g. 1998 for 1998/99. Timings of leaf fall peak located at the beginning of the second year are expressed as greater than month 12, e.g. 13.5 for the middle of January. The duration of full canopy was calculated for each tree by difference between the timings of leaf fall peak and leaf flush peak.

Year effects on the duration of full canopy and the timings of leaf flush peak and leaf fall peak

124 were tested using a repeated-measures analysis of variance (SAS proc. Mixed, SAS Institute Inc. 1999). Potential influence of environmental variables (edaphic or atmospheric) on changes in canopy

126 fullness, were investigated by regression analysis between values of canopy fullness and each variable, considering all trees and pooling data for all of the years. For atmospheric variables (temperature, relative humidity and vapour pressure deficit), the average value for the 15 days preceding phenological observations was considered. For soil water availability, the actual SWA and the amount of rainfall were used. Since at the tree level, canopy fullness values were qualitative and ordinal response variables, classified as $0,5,30$ and 75 , we specifically performed ordered polynomial logistic regressions with a cumulative logit link (SAS proc. Genmod, SAS Institute Inc. 1999). This model relates the cumulative log of odds of the response variable to the explanatory variable in a linear form

134 (Agresti 1984). We assessed the validity of the regression by computing the significance of each variable using Wald tests (Agresti 1984). Because we wanted to compare the predictive power of 136 environmental variables, the c statistic was computed (Hosmer and Lesmehow 2000). It measures the degree to which predicted probabilities agree with actual outcomes. The c statistic ranges from 0.5 to

138 1. A 0.5 value means that the model is no better than assigning observations randomly into outcome categories. Variables with c statistic value greater than $80 \%$ were therefore selected as having high predictive power. The analysis gives the values of the explanatory variable (environmental variable) corresponding to the selected probability of each response $(0,5,30,75)$. For environmental variables

142 having good predictive power, regressions were used to predict for each year, the times of leaf flush and leaf fall peaks such as the day when the probability of full canopy (response 75) rose above or fell 
preceding each day. Quality of prediction was evaluated by the root mean square error: $R M S E=\sqrt{\sum_{1}^{n}\left(s_{i}-m_{i}\right)^{2} / n}, \quad s_{i}$ is the model prediction, $m_{i}$ the corresponding observation, $i$ the year and $n$ the total number of years.

\section{RESULTS}

150 During the study period (1995-2000), annual precipitation averaged $230 \mathrm{~mm}$ with minima of 146 and $153 \mathrm{~mm}$ in 1997 and 1996, and a maximum of $367 \mathrm{~mm}$ in 1999 (Table 1, Fig. 1a). It is noteworthy that inter-annual variability over the six year period $(\mathrm{C} . \mathrm{V} .=37 \%)$ was similar to the long-term variability for the area. Rains occurred mainly between July and September. The dates for onset of the rains were variable, i.e. about the start of June in 1996 and 1997, but the end of July in 1998. August and September were the wettest months. On average, $70 \%$ of the total annual precipitation fell during these 2 months. SWA in the upper layer $(0-100 \mathrm{~cm})$ was closely correlated with annual rainfall (Fig. 1b). In the wet season, SWA increased proportionally with rainfall and reached $80 \%$ for the wettest year 1999. However, by January, SWA decreased to similar values between years, (from 7 to $9 \%$ ). Subsequently, SWA declined to small values of 3 to $5 \%$, before the start of the rains.

Atmospheric conditions in the rainy season were characterized by highest relative humidities $(\mathrm{RH})$, above $50 \%$, with mean temperatures around $30^{\circ} \mathrm{C}$ (Fig. 1a). This was the time of the lowest evaporative demand: daily means of vapor pressure deficit (VPD) were less than $2 \mathrm{kPa}$ (Fig. 1b). $\mathrm{RH}$ increased between May and June, from one to two months before the start of the rains. This is a common phenomenon induced by the northerly movement of the Inter-Tropical Convergence Zone but there were notable differences between years (Fig. 1a). RH decreased sharply after the rainy season, then it fluctuated, from 10 to $50 \%$, with notable differences between years. In the dry season, two climatic seasons are usually distinguished according to air temperature: the "cool" dry season lasting from December until February and the hot dry season lasting from March until June (Fig.1b, month 15 to 17). The hot dry season with low RH and increasing temperatures is characterized by the highest evaporative demand: mean VPD generally exceeds $2 \mathrm{kPa}$ and maximum VPD regularly exceeds $5 \mathrm{kPa}$. 
Evolution of Canopy fullness showed an annual cycle with both similarities and differences

172 between years (Fig. 1b, Table 1). The defoliation phase was centred around the hot dry season. Defoliation was never complete at population scale as shown by Canopy fullness which never reached

174 a zero value (Fig. 1b). The point closest to zero occurred in April 2000 (Fig. 1a: point at 16 mo. in "1999" or 4 mo. in "2000"), which corresponded to $63 \%$ of fully defoliated trees. The full canopy

176 stage lasted an average 7 months (Table 1), from mid-July to the start of February, broadly including the rainy and cool dry seasons (Fig. 1). The inter-annual variation of full canopy stage duration was

178 large, e.g. more than two months between the extreme years: 5.2 mo. in 1996 and 7.5 mo. in 1998 or 1999 (Table 1). The repeated-measures analysis of variance revealed a highly significant $(\mathrm{P}<0.001)$

180 effect of year on canopy duration. The observation interval which was at the best biweekly and more often monthly, precludes discussion of differences or equalities at less than 0.5 months. The magnitude of differences clearly distinguishes two groups, the group of the years 1996 and 1997 where duration was shortened by $25 \%$ in comparison with the group of the years 1995,1998 and 184 1999. The duration differences resulted from variation in a two month range both in the timings of peaks for leaf flush and leaf fall (Table 1). The timing of leaf flush peak varied from the start of June (years 2000, 1999), more than one month before the first rains (Fig. 1), to the end of July in the rainy season (years 1995,1996,1997). The situation in 1998 was intermediate: the start of leaf flushing was early, in May as in 1999 and 2000, but was followed by a defoliation before leaf flush peaked in July (Fig. 1). The timing of leaf fall peak varied from the start of January (year 1996) to the start of March (year 1995). The years 1996 and 1997 had intermediate defoliation in December. The inter-individual variation was large and variable depending upon year (standard deviation in Table 1). For example, for 192 the same average timing of leaf flush peak, the inter-individual variation was fourfold larger in 1999 than in 2000. Similar results occurred between 1995 and 1996 for the timing of leaf fall peak. At the individual level, the time between the onset of flushing and full foliation was approximately 1 to 1.5 mo (data not shown). Figure $1 \mathrm{~b}$ shows the average of canopy fullness in the population, so durations were increased by an averaging effect in the case of large inter-individual variation.

The influence of SWA on the inter-annual variation of canopy phenology could involve ground water and/or upper soil water. The top of the water table was found at $31 \mathrm{~m} \mathrm{depth,} \mathrm{consistent}$ 
with the water level found in village wells in the study area. Between the upper layer of soil and the water table, SWA for plants was very limited because the actual moisture contents were equivalent to a water potential of $-1.5 \mathrm{MPa}$. Living root fragments of $A$. tortilis, which can be identified from their very special smell, were collected at $25 \mathrm{~m}$ depth. These confirmed that the trees have access to the water table. However no fluctuations of the deep water table which could explain inter-seasonal variability of leaf phenology, are known in the area (Gaye and Edmunds 1996).

Results of regression analysis between canopy fullness and environmental variables over all 206 years are summarized in Table 2. For upper SWA, two variables were considered: the actual SWA and the amount of rainfall in the 15 days preceding phenological observations. In the completely dry season (timing of leaf fall), changes of SWA were slow and actual SWA, measured at monthly intervals, was a good integrator of soil conditions for the 15 day period of time. By contrast, during the transition between dry and rainy seasons (timing of leaf flush), due to the effect of rainfall, measured SWA was a poor predictor and rainfall amount (hourly recording) was used as a surrogate (see Fig. 1).

212 Whatever the analysis, there was a significant relationship $(\mathrm{P}<0.05)$ with all environmental variables. This was due to the fact that during the considered periods, soil water and atmospheric variables were

214 all moving broadly at the same seasonal time as canopy fullness (See Fig. 1). The key point is the comparison between predictive powers of variables (c values in Table 2). For the whole time of 216 deciduousness (mainly from January to August), VPDmax is from far a higher predictive variable than SWA or rainfall (Table 2). VPDmax is the value measured around midday, which defines the maximum evaporative demand during the day. The value of VPDmax corresponding to a prediction of $50 \%$ of canopy fullness was $4.8 \mathrm{kPa}$.

When the time of deciduousness was divided between times of leaf flush and leaf fall, there was a remarkable switch between the predictive powers of relative humidity $(\mathrm{RH})$ and temperature (Ta), which are combined in VPD (Table 2). During the time of leaf flush, RH and VPD are the variables which best predicted canopy fullness. During the time of leaf fall, temperature and VPD are 224 the variables which best predicted canopy fullness. The same analysis considering a period of 30 days before phenological observations gave similar results (data not shown). 
Regression analyses were performed pooling all of the years. For environmental variables having a high predictive power, regressions were used to predict for each year, the timings of leaf flush and leaf fall peaks. Inputs were climatic data for the 15 days preceding each date. The day when the probability of full canopy rose above (leaf flush) or fell below (leaf fall) the $50 \%$ value in the long term (> 1 month) was retained. The precision of "long term" is particularly important for the prediction of the date of leaf fall peak because the dynamics of climatic variables fluctuated strongly at this time (see Fig. 1). Root mean square errors of predictions are given in Table 2 and detailed results for VPDmax are shown in Figure 2. Atmospheric conditions explained a large part of interannual variation in both the timing of leaf flush peak $(\mathrm{RMSE}=0.4-0.5$ month) and the timing of leaf fall peak $($ RMSE $=0.6-0.7$ month, Table 2). Finally, combination of Figures $2 \mathrm{a}$ and $2 \mathrm{~b}$ illustrates that VPDmax can explain a part of the duration and period of canopy fullness for the 5 complete years of the study $(\mathrm{RMSE}=0.8)$. The period containing October and November was not considered in the regression-prediction analysis, however, simulations based on atmospheric conditions also predict defoliation for this period, which was not systematically observed (Fig. 1).

242 The full canopy stage of $A$. tortilis sp. raddiana lasts between 5 and 8 months, broadly including the rainy season and the "cool" dry season. The seasonal period and duration of full canopy stage is in agreement with general description of its leaf phenology in Sahelian Africa (Grouzis and Sicot 1980, Diouf and Zaafouri 2003). As with the majority of species in the seasonally dry tropics, the defoliation 246 phase was centered around the hot dry season.

The first main result of this study was large inter-annual variation in the start and end of the

248 full canopy stage on the same site, more than 2 months in each case. One consequence was a $25 \%$ shortfall of the stage duration for two of the years (1996 and 1997). Such variation confirms that genetics and day length cannot be the unique controlling factors of canopy phenology and that other factors have complementary influence on the timings of leaf flush and leaf fall peaks. We should insist 252 that here we deal with the major timing of leaf flush and not initial leaf flush which is often discussed in the literature (Borchert 1994c). Initial leaf flush was generally observed between April and May. 
254 Finally we discuss which factors influence the timing of the massive leaf flush which follows the initial leaf flush.

The second main result was that atmospheric conditions and particularly VPDmax could explain inter-annual change of canopy fullness better than upper or deep SWA. The influence of annual rainfall on canopy phenology through upper SWA is a current hypothesis in the Sahelian zone : higher rainfall would induce a larger residual upper soil water availability in the dry season which could delay the timing of defoliation and would advance the time of leaf flushing peak. Our results do not support this hypothesis despite a large inter-annual variation in rainfall (from $146 \mathrm{~mm}$ in 1997 to

$262367 \mathrm{~mm}$ in 1999). It was particularly notable that three month after rainy season, upper SWA reached similar and very small values in all years. How was this possible? The phenological stage or canopy 264 fullness percentage does not describe leaf number or area which were two times higher for the wettest years, 1998 and 1999 than for 1997 (Goudiaby 2003). Biomass of grass was also greater at the end of 266 the wettest rainy seasons. These two factors involve greater water uptake, which can explain how SWA reached similar small values.

The third main result was that atmospheric conditions and particularly VPDmax predicted a significant part of the inter-annual variations in both the timing of leaf flush peak and of leaf fall peak.

270 We conclude that these inter-annual variations of canopy phenology were mainly controlled by atmospheric conditions. Comparable data on this point are scarce in the literature although the possible influence of relative humidity on leaf flush was often hypothesized. One reason may be that phenological studies on the same individuals, which last for more than one or two years, are rare in the

274 tropics. Another reason could be that until now, VPD was not always considered as a climatic variable influencing savanna tree phenology (De Bie et al. 1998, Chidumayo 2001). Moreover, the conditions 276 of water constraint (rainfall amount, evaporative demand and depth to the water table) in the ecosystem studied here were more extreme than in savanna situations detailed elsewhere in the literature (Eamus and Prior 2001). However, an inter-annual analysis with "only" 5 to 6 years cannot definitively demonstrate that VPD is a major proximal cue of canopy phenology in the dry tropics.

280 Nevertheless, the results give a new and clear insight on the influence of atmospheric conditions. 
What would be the adaptative significance of such response to atmospheric conditions? This behaviour leads to maximization of the duration of canopy fullness below a VPD threshold between 4.5 and $4.9 \mathrm{kPa}$. Such behaviour maximizes the duration of photosynthetic activity under a threshold of evaporative demand and does not reduce water loss. Field observation at the terminal branch scale in 1997 and 1998 showed, that the annual phenological pattern corresponds to three main cohorts of leaves (Goudiaby, 2003). The first cohort begins between April and May, the second cohort begins in July and the last begins between December and January. The cohort of July expressed the longest leaf life span around 6-7 months. The life span of the initial and final cohorts was very short and variable depending upon the year. Leaf stomata are known to be very sensitive to VPD. We hypothesize that the response of the two extreme cohorts of leaves to climatic conditions could explain inter-annual variation of canopy phenology.

Do these results mean that soil water availability has no influence on leaf phenology of Acacia tortilis? We do not support this. Firstly, leaf activity of trees during large periods of the dry season is only possible because trees have access to extra-annual water in the deep soil. Secondly, the existence of large spatial variation in canopy deciduousness at the landscape scale suggests a strong effect of SWA.

296 It was particularly notable at the border of the Senegal river, near Dagana city, where the water table is close to the top soil that the tree population behaves like an evergreen species. Finally, we believe that the average phenological pattern fits the prevailing local SWA's, annual rainfall amount and depth to the water table. While the inter-annual variation of canopy phenology is a fine tuning to atmospheric conditions.

In conclusion, if such large inter-annual variation of canopy phenology is common to other dominant species of the seasonally dry tropics, which is fairly possible, the consequences for the potential impact of climate change are important and not only rainfall should be considered.

\section{ACKNOWLEDGEMENTS}

We thank Youm Mbaye, Hyacinthe Tendeng and Baïdi Li for technical assistance. We are grateful to 
Commission contract INCO-DC «Minimizing competition in dryland agroforestry Contract No.

ERBIC 18CT 98 0322». We specially thank J.D. Deans for English revision.

\section{LITERATURE Cited}

Agresti, A. (1984). Analysis of ordinal categorical data. New York: Wiley.

Berger A., Grouzis M., Fournier C., 1996. The water status of six woody species coexisting in the Sahel (Ferlo, Senegal). J. Trop. Ecol. 12: 607-627.

Borchert, R. 1994a. Soil and stem water storage determine phenology and distribution of tropical dry forest trees. Ecology 75:1437-1449.

Borchert, R. 1994b. Water status and development of tropical trees during seasonal drought. Trees 8:115-125.

Borchert, R. 1994c. Induction of rehydration and bud break by irrigation or rain in deciduous trees of a tropical dry forest in Costa Rica. Trees 8:115-125.

Borchert, R. 1998. Responses of tropical trees to rainfall seasonality and its long-term changes. Climatic Change 39:381-393.

Breman, H. and J-J. Kessler. 1995. Woody plants in Agro-Ecosystems of Semi-Arid Regions, with Emphasis on the Sahelian Countries. Springer-Verlag Berlin Heidelberg, Germany.

Chidumayo, E. N. 2001. Climate and phenology of savanna vegetation in southern Africa. Journal of Vegetation Science 12:347-354.

Corlett, R. T. and JR. J. Lafrankie. 1998. Potential impacts of climate change on tropical asian forest through influence on phenology. Climatic. Change 39:439-453.

De Bie, S., P. Ketner, M. Paase and C. Geerling. 1998. Woody plant phenology in the West Africa savanna. Journal of Biogeography 25:883-900.

Deans, J. D., W. M. Edmunds, D. K. Lindley, C. B. Gaye, B. Dreyfus, J. Nizinski, M. Neyra, R.C. Munro, K. Ingleby. 2004. Nitrogen in interstitial waters in the Sahel: Natural Baseline, Pollutant or resource? Plant and Soil, in press. 
332 Do F. \& A. Rocheteau 2003. Cycle annuel de transpiration d'Acacia raddiana par la mesure des flux de sève brute (Nord-Sénégal). In "Un arbre au désert: Acacia raddiana", Editeurs scientifiques M. Grouzis et E. Le Floc'h, IRD éditions, Paris, pp. 119-142.

Duff, G. A., B. A. Myers, R. J. Williams, D. Eamus, A. O’Grady and I. R. Fordyce 1997. Seasonal patterns in soil moisture, vapour pressure deficit, tree canopy cover and predawn water potential in a northern Australian savanna. Australian Journal of Botany 45:211-224.

Diouf M. \& M. S. Zaafouri, 2003. Phénologie comparée d'Acacia raddiana au nord et au sud du Sahara. In "Un arbre au désert: Acacia raddiana", Editeurs scientifiques M. Grouzis et E. Le Floc'h, IRD éditions, Paris, pp. 103-118.

Eamus, D. and L. Prior. 2001. Ecophysiology of trees of seasonally dry tropics: Comparisons among phenologies. Advances in Ecological Research. 32:113-197.

Gaye, C. B. and W. M. Edmunds. 1996. Groundwater recharge estimation using chloride, stable isotopes and tritium profiles in the sands of north-western Senegal. Environmental Geology 27:246-251

Goudiaby V.C.A. 2003. Impact d'un déficit pluviométrique sur la feuillaison d'Acacia tortilis (Forsk.) Hayne subsp. raddiana (Savi) Brenan var. raddiana dans le Nord-Ferlo au Sénégal. Thèse de Doctorat, Faculté des Sciences et Techniques, Université Cheikh Anta Diop, DAKAR, 82 p.

Grouzis, M. \& M. Sicot. 1980. A method for the phenological study of browse populations in the Sahel: the influence of some ecological factors. Pages 233-240 in H. N. Le Houérou, editor. Browse in Africa : The current state of knowledge. ILCA edition, Addis Abeba, Ethiopia.

Halevy, G. and G. Orshan. 1973. Ecological studies on Acacia species in the Negev and Sinai: II. Phenology of Acacia raddiana, A. tortilis and A. Gerrardii negevensis. Israelian Journal of Botany 22:120-138.

Hosmer, D. W., Jr., \& S. Lemeshow (2000). Applied logistic regression (2nd ed.). New York: Wiley.

IPCC. Climate change 2001: Impacts, Adaptation, and Vulnerability. Cambridge University Press, New York, USA. 
358 Le Floc'h E. \& M. Grouzis, 2003. Acacia raddiana, un arbre des zones arides à usages multiples. In "Un arbre au désert: Acacia raddiana”, Editeurs scientifiques M. Grouzis et E. Le Floc'h, IRD éditions, Paris, pp. 21-58.

Le Houérou, H. N. 1989. The grazing land ecosystems of the African Sahel. Ecological studies, Volume 75, Springer-Verlag, Berlin.

Lhote, H. 1961. Au sujet de l'arbre du Ténéré. Bulletin de liaison Saharienne 12:49-54.

364 Morellato, L.P.C., D.C. Talora, A Takahasi, C.C. Bencke, E.C. Romera, and V.B. Zipparo 2000. Phenology of atlantic forest trees: A comparative study. Biotropica 32(4b):811-823.

366 Myers, B. A., R. J. Williams, I. Fordyce, G. A. Duff \& D. Eamus 1998. Does irrigation affect leaf phenology in deciduous and evergreen trees of the savannas of northern Australia? Australian Journal of Ecology 23:329-339.

Poupon H. 1979. Etude de la phénologie de la strate ligneuse à Fété Olé (Sénégal septentrional) de 1971 à 1977. Bulletin de l'IFAN, Tome 41, série A, nº 1:44-85.

Reich, P. B. 1995. Phenology of tropical forest: patterns, causes, and consequences. Canadian Journal of Botany 73:164-174.

Reich, P. B. \& , R. Borchert 1984. Water stress and tree phenology in tropical dry forest in the lowlands of Costa Rica. Journal of Ecology 72:61-74.

SAS Institute Inc. (1999). SAS/STAT® user's guide (Version 8, Vol. 2). Cary, NC: SAS Institute Inc.

Williams, R. J., B. A. Myers, W. J. Muller, G. A. Duff, \& D. Eamus. 1997. Leaf phenology of woody species in a north Australian tropical savanna. Ecology 78(8):2542-2558.

378 Wright, S. J. \& Cornejo, F. H. 1990. Seasonal drought and leaf fall in a tropical forest. Ecology 71:1165-1175. 


\section{LIST OF FIGURES}

Figure 1: Inter-annual variation of environmental conditions and leaf phenology for Acacia tortilis growing at Souilène in North Senegal. a) daily rainfall, 15 days moving average of mean air temperature and relative humidity $(\mathrm{RH})$ b) average Canopy Fullness of 39 individuals, Soil Water Availability (SWA) in the upper layer (0-1 m), 15 days moving average of mean air vapour pressure deficit (VPD). Time is expressed in numerical values of months, e.g. 6.5 for the middle of June. The study ended in August 2000.

Figure 2: Timings of leaf flush peak (a) and leaf fall peak (b) predicted by models based on the dynamics of maximum vapour pressure deficit (VPDmax) versus observed timings. Input was the average value of VPDmax for the preceding 15 days. Point labels specify annual phenological cycles. Horizontal bars indicate standard deviation of observed data (means of 39 individuals). RMSE is the root mean square error (see methods).

\section{LIST OF TABLES}

Table 1: Mean values of timing of leaf flush peak, timing of leaf fall peak, and duration of full canopy stage expressed in months for 39 individuals of Acacia tortilis growing at Souilène in North Senegal. Repeated-measures ANOVA revealed highly significant effects of year $(\mathrm{P}<0.001)$ on the three variables. The study ended in August 2000 before observation of the timing of leaf fall for the phenological cycle 2000-01.

Table 2. Parameters of regression-prediction analysis testing which environmental variable can best explains inter-annual changes in canopy fullness (CF) and the timings of leaf fall and leaf flush peaks (50\% of CF). Variables were upper soil water availability (SWA), rainfall and daily mean, minimum and maximum air temperatures $(\mathrm{T})$, relative humidity $(\mathrm{RH})$ and vapour pressure deficit (VPD). Polynomial logistic regressions were performed (see methods). C is the predictive power, which is high when $\left(^{*}\right)$ is added. $50 \% \mathrm{CF}$ indicates the value of variables 
corresponding to $50 \%$ of Canopy Fullness. RMSE is root mean square error of predicted timings of leaf fall and leaf flush peaks against observed timings. 